\begin{tabular}{|c|c|c|c|}
\hline \multirow{2}{*}{ 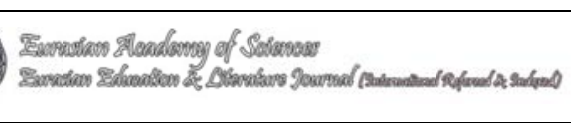 } & \multicolumn{3}{|c|}{$\begin{array}{c}\text { Eurasian Academy of Sciences } \\
\text { Eurasian Education \& Literature Journal }\end{array}$} \\
\hline & 2015 & Volume:1 & S: $31-42$ \\
\hline \multicolumn{4}{|c|}{$\begin{array}{l}\text { Published Online April } 2015 \text { (http://edulit.eurasianacademy.org) } \\
\text { http://dx.doi.org/10.17740/eas.edu.2015-V1-03 }\end{array}$} \\
\hline
\end{tabular}

\title{
THE PLACE OF TALE GENRE IN EDUCATION AND ITS USABILITY IN TURKISH TEXTBOOKS
}

Neslihan Karakuş*, Neşe Işık **

Yıldız Teknik Üniversitesi*, Esenyurt Üniversitesi**

E-mail: neslihanoksuz61@gmail.com*,neseisik@gmail.com**

Copyright (C) 2015 Neslihan Karakuş, Neşe Işık. This is an open access article distributed under the Eurasian Academy of Sciences License, which permits unrestricted use, distribution, and reproduction in any medium, provided the original work is properly cited.

\begin{abstract}
The genres of epic, tale, legend, fairy tale and folk tale are like a precious treasure among the narration-based genres and they are a kind of a carrier of Turkish cultural traditions. In the oral tradition, tales have a different significance. Usually created by people, dream-based, living in oral tradition, explaining the extraordinary events which happen to mostly people, witches and animals, demons, giants, and fairies; defined as the story that is developed by extraordinary people and events, the tales have a great impact in the development of the students' imaginations. In the first part of the study, the nature and the meaning of the tale genre, and its importance in Turkish Literature and Culture is explained; in the second part, the question, purpose, method and limitations of the research have been discussed; the third section focuses on the usability of the tales in order to meet the needs of the source text in Turkish Education and emphasizes its importance by studying the determination of its functions in education. The aim of the study is to determine the usability of the tales which are also the passer of oral cultural tradition as a source text in Turkish teaching. The research is a descriptive study which is a document analysis. A literature review has been conducted and the findings section is made by the obtained information and it is come to a conclusion that the tales should be used in Turkish education. Also at what rate this literary genre is used in the secondary school textbooks by Turkish Ministry of Education has been identified, and it has been concluded that there are some shortcomings in this subject.
\end{abstract}

Keywords: Tales, oral cultural tradition, Turkish Education, Turkish textbooks, the source text.

\section{Masal Türünün Eğitimdeki Yeri ve Türkçe Ders Kitaplarındaki Kullanılabilirliği}

ÖZET: Anlatmaya dayalı türler içerisinde kıymetli birer hazine değeri taşıyan destan, masal, efsane, masal ve halk hikâyeleri Türk kültür geleneğinin birer taşıyıcısı konumundadır. Sözlü gelenek içerisinde masalların ise ayrı bir önemi vardır. Genellikle halkın oluşturduğu, hayale 
dayanan, sözlü gelenekte yaşayan, çoğunlukla insanlar, hayvanlar ile cadı, cin, dev, peri gibi varlıkların başından geçen olağanüstü olayları anlatan; olağanüstü kişiler ve olaylarla geliştirilen öykü olarak tanımlanan masallar öğrencilerinin hayal gücünü geliştirmede büyük bir yere sahiptir. Çalışmanın birinci bölümünde masal türünün anlamına, mahiyetine, Türk Edebiyatında ve Türk Kültüründeki önemine yer verilmiş; ikinci bölümünde araştırmanın problem sorusu, amacı, yöntemi, sınırlılıkları izah edilmiş; üçüncü bölümünde ise Türkçe Eğitiminde kaynak metin ihtiyacını karşılamak için masalların kullanılabilirliği üzerinde durulmuş ve eğitimdeki işlevlerinin tespitine çalışılarak önemi vurgulanmıştır. Çalışmanın amacı; sözlü kültür geleneğinin aktarıcısı olan masalların, Türkçe öğretiminde kaynak metin olarak kullanılabilirliğini tespit etmektir. Araştırma, doküman incelemesi yöntemi ile hazırlanmıştır. Yapılan inceleme sonucu elde edilen bilgilerle bulgular bölümü oluşturularak masalların Türkçe Eğitiminde kullanılması gerektiği görüşüne varılmıştır. Ayrıca Millî Eğitim Bakanlığı Yayınlarına ait ilköğretim ikinci kademe Türkçe ders kitaplarında bu edebî türün hangi oranda kullanıldığ 1 tespit edilerek, bu konuda eksiklikler olduğu sonucuna ulaşılmıştır.

Anahtar Kelimeler: Masal, sözlü kültür geleneği, Türkçe Eğitimi, Türkçe ders kitapları, kaynak metinler.

\section{Giriş}

\subsection{Masalın Tanımı}

Masal, dünya edebiyatında ortak sözlü anlatım türlerinin başında gelir. Masalların bölgesel özellikleri, farklı kültürel yapıları bünyesinde taşıdığı da bilinmektedir. Yaklaşık yüz elli yıldan beri üzerinde çalışmalar yapılan masalın tarifi netlik kazanmamıştır. Türk Dünyası'nda değişik kelimelerle ifade edilen masal, Anadolu ve Balkan Türklerinin diline Arapça mesel kelimesinden girmiştir. Azerbaycan Türkçesinde nağıl, Kazak Türkçesinde sabuv veya eşabıs, Özbek Türkçesi'nde ertâk, Türkmen Türkçesi'nde erteki, Uygur Türkçesi”nde çöcak şeklinde telaffuz edilmektedir. (Türk Lehçeleri Sözlüğü, 1991: 562-563 ). Ayrıca dâsitân, kıssa-i meşhure gibi adlarla da anıldığı görülür.

Bugüne kadar pek çok araştırmacı, yazar masallarla ilgili farklı tarifler yapmıştır. Bu tariflerden masal araştırmalarına önemli katkılar yapmış Saim Sakaoğlu, Ali Berat Alptekin ve Esma Şimşek'in tariflerini verdikten sonra, ansiklopediler ve sözlüklerdeki masal tariflerine yer verilecektir.

Saim Sakaoğlu (2002: 2), "Gümüşhane ve Bayburt Masalları" adlı eserinde masalı: "Kahramanlarından bazıları hayvanlar ve tabiatüstü varlıklar olan, olayları masal ülkesinde cereyan eden, hayal mahsulü olduğu hâlde, dinleyicileri inandırabilen, bir sözlü anlatım türüdür" şeklinde tarif eder. "Taşeli Masalları adlı" eserinin ön sözünde Ali Berat Alptekin (2002: 12): "Masal nesirle söylenmiş ve dinleyicileri inandırmak gibi bir iddiası olmayan, tamamı ile hayal mahsulü olan mensur bir türdür." şeklinde tanımlar.

Esma Şimşek, Yukurıçukurova Masallarında Motif ve Tip Araştırmaşları adlı eserinde masallarla ilgili geçmiş dönemlerde yapılan tariflerini verdikten sonra, kendisi de“Genellikle özel kişiler tarafindan, kendine mahsus (olağanüstü) zaman, mekân ve şahıs kadrosu içerisinde, yaşanılan hayat ile hayal edilen hayatın sistemli bir şekilde ifade edildiği; klişe 
sözlerle başlayıp, yine klişe sözlerle biten hayal mahsulü sözlü anlatım türüdür.” (Şimşek; 2001: 3) şeklinde masal tarifi yapar.

TDK Büyük Türkçe Sözlük’te; “Genellikle halkın yarattığı, hayale dayanan, sözlü gelenekte yaşayan, çoğunlukla insanlar, hayvanlar ile cadı, cin, dev, peri vb. varlıkların başından geçen olağanüstü olayları anlatan edebî tür"; Türk Ansiklopedisi'nde: "Masal, olaylarının geçtiği yer ve zamanı belirli olmayan, peri ve cin, dev, ejderha, cadı karı, Arap, padişah, vezir gibi kahramanları belirli kişileri temsil etmeyen hikâye" (Tezel, 1973:317); Büyük Larousse’ta: "Bütünüyle hayal ürünü olan, genellikle olağanüstü olaylara zaman zaman da olağanüstü varlıklara yer verilen, olayları çoklukla belirli olmayan bir yerde (masal ülkesinde), belirli olmayan bir zamanda (evvel zaman içinde) geçen bir anlatı türü." (Büyük Laouresse, 1992:2841) olarak tanımlanmıştır.

"Masal; birtakım olağanüstülükleri içine alarak insanları eğlendiren, insanlara ders veren, öğüt veren, geçmişin tecrübelerini tatlı bir dille gelecek nesillere aktaran, bütün bu özelliklerini bir kalıp içerisinde sunan anlatım türüdür." (Öcal, 2002 :114)

Mustafa Ruhi Şirin; masalı geçmişle gelecek arasındaki köprü olarak tanımlarken masalın insanın iç dünyasını yansıtan bir ayna olduğunu vurgular. "Klasik masallar, tarihin derinliklerinde doğmuş olmalarına rağmen çağları aşarak hafizalara yerleşmeyi başarmış sözlü anlatımın ufuk çizgisini oluştururlar. Zamanın akışı içinde, içinden çıktıkları toplumla birlikte varlıklarını sürdürürler. Gelenek taşıyıcıları olan klasik masallar, geçmişle gelecek arasındaki insan düşüncesinin soyut resimlerini soyut masal çizgileri ile çizerler. Hep insana dönük, insanın içine bakışı yansıtan aynaları sunarlar insana.” (Şirin, 1998:36) Masallar, insan ruhunun aynalarıdır ve halk edebiyatının insanı, insana anlatan halk önemli bir kültür ürünüdür.

\subsection{Türk Edebiyatı'nda Masal}

Türk masalları üzerine yapılan yabancı araştırmacıların çalışmaları ve Ziya Gökalp, Hamit Zübeyir Koşay gibi pek çok değerli araştırmacıyla başlamış, günümüze kadar devam etmiştir. Türk masalları, 18. yüzyılın sonlarında Batılı araştırmacıların da ilgisini çekmiştir. Türk masalları üzerine yayınlanmış en eski derleme M. Diegon'a aittir. Nouveaux Contes Turc et Arabes (1781, Yeni Türk ve Arap Masalları) adlı bu yapıtının ikinci cildinde üç Türk masalı yer alır. V. Radlov'un, Türk halk edebiyatından yaptığı derlemeleri içeren on ciltlik Proben der Türkischen Stamme (1866-1907, Türk Kavimlerinin Halk Edebiyatından Örnekler) adlı yapıtıyla, Macar Türkolog İ. Kunos'un 1887-1907 arasında beş cilt olarak yayınlanan masal kitaplarında da, Anadolu ve Rumeli'den derlenmiş çok sayıda masal bulunmaktadır. Türk masallarını derleme ve yayınlama çalışmaları Cumhuriyet Dönemi'nde yoğunlaşmış Ziya Gökalp, Eflatun Cem Güney, Tahir Alangu ve Naki Tezel derledikleri masalları edebî bir biçim vererek yayınlamışlardır. Başta Pertev Naili Boratav olmak üzere Mehmet Tuğrul, Warren Walker, Barbara Walker gibi yazar ve araştırmacılar da Türk masalları üzerine derlemeler ve incelemeler yapmışlardır. Boratav, W Eberhard'la birlikte hazırladığı Typen Türkischer Volksmarchen (1953, Türk Halk Masallarının Tipleri) adlı çallşmada, 2500 Türk masalını inceleyerek 378 masal tipine yer verir. (Boratav, 2001: 3) 
$\mathrm{Bu}$ alanda, bu eserlerin dışında çok sayıda kitap yazılmış, makaleler hazırlanmış, yüksek lisans ve doktora tezleriyle masal çalışmaları Türk dünyasını da içine alacak şekilde geniş bir coğrafyaya yayılmıştır. Türkiye'de masallarla ilgili gerek akademik düzeyde hazırlanmış gerekse masallarla ilgilenen araştırmacıların yaptığı çalışma sayısının oldukça fazla olması sebebiyle burada yalnızca doktora çalışması düzeyinde eser veren başlıca birkaç araştırmaya değinilecektir.

Türk Halk Edebiyatı'na önemli katkılar sağlamış Prof. Dr. Saim Sakaoğlu, ilk olarak masallar üzerine yapılan doktora çalışmasıyla çok kıymetli bir eseri Türk Halk Edebiyatı'na kazandırmıştır. Saim Sakaoğlu, Gümüşhane Masalları Metin Toplama ve Tahlil adlı doktora tezinde "Türk Halk Masalları" adlı bölümde masal kitaplarından, dergilerdeki derleme faaliyetlerinden, diğer kaynaklardaki faaliyetlerden, öğrenci tezlerinden ve masallar üzerine yapılan ilmî çalışmalardan ayrıntılı bir şekilde söz eder. Prof. Dr. Bilge Seyidoğlu da, Erzurum Halk Masalları Üzerinde Araştırmalar adlı doktora çalışmasında masallar üzerine yapılan çalışmalar üzerinde durmuştur. Bu alanın önemli isimlerinden, Prof. Dr. Umay Günay’ın Elazığ Masalları adlı doktora çalışmasında da geçmiş yıllardaki masal çalışmalarına değinilir. Pof. Dr. Ali Berat Alptekin'in Taşeli Platosu Masallarında Motif ve Tip Araştırması adlı doktora tezinde de masallar üzerine yapılmış çalışmalara yer verilmiştir. Prof. Dr. Esma Şimşek'in, Yukarı Çukurova Masallarında Motif ve Tip Araştırması adlı doktora tezinde 1982 yılından önce ve 1982 yılından sonra yapılmış masal çalışmaları ayrıntılı bir şekilde değerlendirilmiştir. Türk Masallarının Sembolik Açıdan Çözümlenmesi adlı doktora teziyle masallara farklı bir açıdan yaklaşan Dr. Neşe Işık’ın çalışması da alana katkı sağlayıcı niteliktedir.

\subsection{Türkçe Eğitiminde Kaynak Metin İhtiyacı}

Kaynak Metinler; Toplum içinde yaşayan ve o toplumu oluşturan fertlerden biri tarafindan oluşturulan ve toplumun yaşayışını, geleneklerini, dilini, ahlak anlayışını, değerlerini kişiden kişiye, kuşaktan kuşağa ileten eserlerdir. Yazıldıkları toplum ve dönemle sıkı bir ilişki içerisindeki bu metinler dilin ve kültürün gelecek nesillere aktarılmasını sağlar.

Aslı Arapça olan metin kelimesi; bir yazıyı biçim, anlatım ve noktalama özellikleriyle oluşturan kelimelerin bütünüdür (Tdk, 2005: 1382). Genel manasıyla metin; herhangi bir konu veya olayın dil vasıtasıyla -yazılı veya sözlü olarak- ifadesinden oluşan söz bütünüdür. Yani; herhangi bir konu veya olayı açıklamak/anlatmakla görevli kelimeler, ibareler, deyimler, cümle ve cümlecikler, paragraflardan oluşan "söz ve söylem bütünü"ne metin denir (Çetişli, 2007: 5). Edebiyat biliminin kastettiği ve edebiyat eğitiminde esas olması gereken edebî metin ise; herhangi bir duygu, düşünce, hayal, intiba ve olayın dil vasıtasıyla, ama edebîlik değerine haiz bir biçimde ifadesinden oluşan "söz ve söylem bütünü”dür. Şâir veya yazarın kaleminden çıkmış şiir, hikâye, roman, tiyatro metinleri gibi. Söz ve söylemin metne dönüşmesindeki temel ölçüt, anlam ve mantık bütünlüğüdür.

Dili doğru ve düzgün kullanma doğuştan gelen bir yetenek değil, doğrudan doğruya eğitimle elde edilen bir beceridir. Beceri ise, elverişli ortamda, uygulama ve deneyimlerle kazanılır. Türk Millî Eğitimince Türkçenin öğretimi, örgün eğitim içinde ilköğretimin ilk kademesinde 
başlamaktadır. İlköğretim, ilk okuma yazma öğretimi ile temel dil becerileri olan okuma, yazma, dinleme, konuşmanın temel düzeyde kazandırılmasının, çocuklardla anadili sevgisi ve bilincinin uyandırılmasının amaçlandığı ilk eğitim basamağıdır (Sever: 2004: 9-10). Türkçenin ilköğretim kademelerinde en iyi şekilde öğretilmesinin gerekliliği tartışılmaz bir mecburiyettir.

"Dili sevmek için onu öğrenme gereksinimleri ve öğrenirken kişiye sunulan hizmet çok önemlidir. Öğrenciye bunun bir mecburiyet olmadığını, Türkçe derslerine gösterecekleri ilginin ve o dersten elde edecekleri başarının onlara nasıl bir gelecek hazırlamak için olduğunu her firsatta söylemelidir. Öğrenciler, bu yolla motive edilerek ilgileri açık tutulmalıdır. Bu ilgiyi arttırmak için Türkçenin en güzel metin örnekleri ile onlara hitap etmelidir (Karakuş, 2012: 78; Kavcar vd., 2004: 8-9).”

Edebî metinlerin temel amacı; öğrencinin yaradılışından getirdiği güzellik duygusunu ortaya çıkarmak, geliştirip zenginleştirmek ve terbiye etmektir. "Genç beyin ve ruhlara, evrensel insan ruhunun son derece karmaşık duyarlılıklarını sezdirmek, yüzyılların örsünde dövüle dövüle billurlaşmış millî zevki tattırmak, mensubu bulunduğu milletin hayatı ve kültürünü estetik bir çerçeve içinde tanıtmak, konuştuğu dilin incelikleri, güzellikleri ve zenginliklerini göstermek de edebiyat eğitiminin amaçlarındandır. Kendini bu amaçlara kilitleyen eğitimci ise, ciddî bir bilgi birikimi ve metotlu metin çözümleme tecrübesinin yanında üstün pedagojik formasyonu olan bir sanat eğitimcisidir (Çeşitli, 2006: 8).”

Edebî eserden soyutlanmış bir edebiyat ve dil eğitimi düşünülemez. Bir başka ifadeyle; edebî metnin ihmal edildiği ve sadece tema, proje, kazanımlar gibi teorik izahatın ve ders süresince anlaşılamayacak kadar uzun ve edebîlikten uzak metinlerin öğrenciye sunulduğu bir Türkçe dersi başarıdan uzak olacaktır. Böyle bir gayret, son derece soyut birtakım bilgilerin genç beyinlere yüklenilmesinden başka bir işe yaramayacaktır.

Metin merkezli dil eğitiminde metnin yazarı, içinde hayat bulduğu toplum ve şartlar, bağlı bulunduğu edebî gelenek ve mektep, büyük önem taşır. Hatta felsefe, psikoloji, sosyoloji, tarih, ilahiyat, dilbilimi gibi disiplinlerden de faydalanmak gerekir. Bütün bunlar düşünüldüğünde, kaynak metin niteliğindeki edebî metinlerin Türkçe dersleri için ne kadar büyük önem taşıdığı anlaşılmaktadır (Özden, 2009: 15; Karakuş, 2012). Metin türlerinin zenginliği de Türkçe öğretiminde büyük önem arz etmektedir. Her kitabın farklı metinlere yer vermesi, o farklı metinlerin de öğrenciye değişik kelimeleri ve deyimleri kazandırmaya yönelik çalışmalar içermesi gerekmektedir (Cemiloğlu, 2004: 169).

\subsection{Türkçe Eğitiminde Kaynak Metin Olarak Masal Türünden Yararlanma}

Türkçe eğitiminde masal türünden yararlanmanın pek çok farklı yönü mevcuttur. Yukarıda kaynak metinlere değinilmiş ve kaynak metinlerin Türkçe ders kitapları için ne kadar önemli oldukları üzerinde durulmuştur. Milli Eğitim Bakanlığı Talim ve Terbiye Kurulu tarafindan, 2006 yılında hazırlanmış olan ilköğretim Türkçe dersi öğretim programında belirtilmiş şekliyle "okuma metinlerinde bulunması gereken özellikler" başlığı altında 27 maddeye yer 
verilmiştir. Bu maddeler (MEB, 2006: 56) ve metin oluşturma ölçütleri (Durmuşoğlu, 1987: 106) göz önünde bulundurularak hazırlanacak metinler ders kitaplarına yerleştirilmeye hazır metinler hâline gelecektir (Karakuş, 2012: 26). Böylelikle ders kitaplarında hem farklı türlere, hem de farklı yazarlara yer verilmiş olacak; Türk Edebiyatının seçkin eserleri ders kitaplarında yerini bulacaktır.

İlköğretim ikinci kademede öğrenim gören 12-14 yaş arası gençler için Türkçe ders kitapları diğer ders kitaplarına oranla daha büyük önem arz etmektedir. Öğrenciler gerek Türk Edebiyatı'nın ve gerekse Dünya Edebiyatının en seçkin örnekleri ile karşılaşmalı, metinler her yönden uzman görüşleri alınarak düzenlenmeli, öğrencilerin dil ze:vkini ve bilincini geliştirecek nitelikte olmalıdır. Bu açıdan bakıldığında masal türüne gereken önemin verilmediği gözlemlenmektedir. Oysa masalların, görülenin altında görülmeyen pek çok işlevleri vardır. Çocukların hayal dünyasını zenginleştirir, çocuğu hayata hazırlar, dinleme becerilerinin gelişmesine katkı sağlar, okul öncesi dönemde ve ilk okuma döneminde çocuğun okuma alışkanlığı kazanmasında önemli yere sahiptir, kelime hazinesini geliştirir, çocuğun edebi zevkini arttırır (Arıc1, 2012: 89-93)

\subsection{Türkçe Eğitiminde Kaynak Metin Olarak Masal Türünün İşlevleri}

Bu bölümde, genel olarak öneminden bahsettiğimiz masal türünün, görünmeyen işlevlerinden bahsetmek yerinde olacaktır. On başlık altında toplanacak olan bu işlevler şöyledir:

1. Eğitici Olarak Masallar: Masalların eğitici yönü genel olarak pek görülmez; çünkü olay örgüsünün yoğunluğu masalın eğiticiliğini bastırır. Oysa masallarda çok farklı olaylar birbiri ardı sıra gelebilmekte ve bunların her biri kendi içinde ayrı bir konuya 1şık tutabilmektedir. Masalı okuyan veya dinleyen çocuk, olabilecek olayları hayal dünyasında canlandırırken çeşitli çıkarımlara varabilir. Bu da sezdirme yoluyla eğitime güzel bir zemin hazırlamaktadır. "Masal kahramanı ne yaptığı için ne olmuştur, nasıl yapsa ne olurdu/olmazdı?" Bu soruların her biri ve daha fazlası; çocuğun iç dünyasında kendi kendine sorup, cevaplarını bulabileceği sorulardır. Ayrıca çocuğa, iyi-kötü ayrımını doğru davranışın hangisi olduğunu kavratır.

2. Öğretici Olarak Masallar: Eğitici yönü olan bir edebî tür, öğretici niteliklere de sahiptir. Çok çeşitli olay örgüleri ile kurulan masallar; her ne kadar hayal ürünü olarak nitelendirilseler de, içeriğinden çıkarılabilecek türlü türlü hayat tecrübeleri ile doludurlar. $\mathrm{Bu}$ yönü ile masallar öğreticiliklerini sergilerler. Bunu yaparken dikta etme şeklinde değil, sezinletme metoduyla yaparlar.

3. Düşündürüicü Olarak Masallar: Okuru farkında olmadan onu eğitip, öğreten masallar; bunu okurunu düşündürerek başarırlar. Öğrenciyi; düşünmeye, hayal kurmaya, olmuş olanları kritik etmeye, olabilecekleri planlamaya o bütün bunların farkında olmadan sevk eder. Böylelikle öğrencinin düşünme kabiliyetini geliştirmeye yardımıı olur. 
4. Kültür Aktarıcısı Olarak Masallar: Her kültürün, her milletin, her toplumun kendine özgü masalları vardır. Farklı kültürlere ait masalların öğrenilmesi ile bu kültürlere ait bilinmeyen bir takım özelliklerin de öğrenilebilecek olduğu unutulmamalıdır. $\mathrm{Bu}$ özellikleriyle masallar, kültür aktarıcılığı yapmakta ve bizi bir başka millete anlatırken; başka bir milleti de bize anlatmakta ve onlar hakkında bilgi sahibi olmamıza vesile olmaktadır. Üstelik de bunu yaparken; ne anlatanı, ne de dinleyeni yormaktadır.

5. Gelenek Aktarıcısı Olarak Masallar: Yukarıda kültür aktarıcı özelliği üzerinde durulan masalların gelenek aktarıcı özellikleri de oldukça önemlidir. Bugün anlatılan veya dinlenilen masalların çoğu günümüze ait değildirler. Bunların içerisinde çok eski yüz yıllara ait masallar da mevcuttur. Makalenin başında: "Türk Edebiyatında Masal” başlığı altında bu konuya ayrıntılı olarak değinilmiş ve görülmüştür ki masallar: geçmişi günümüze aktaran çok renkli, göz kamaştırıcı, dinlemeye doyulmayan, tekrar tekrar okunmak istenilen modası geçmeyen klâsiklerdir. İçlerinde barındırdıkları olağanüstülükleri onların en belirgin özelliğidir; fakat bilinmeyen çok eski zamanlara ait olsalar da yaşamaya devam etmekte ve her çağa, her topluma uyum sağlayabilmektedirler.

6. Farklılıkları Gösterici Olarak Masallar: Masalların bu özelliği üzerinde durulurken, içlerindeki iyi kötü çatışmalarını vurgulamak doğru olacaktır. Her masalın mutlaka bir veya birkaç kahramanı vardır. Bu kahramanlar, kötülerle savaş halindedir. İyi- kötü, güçlü-güçsüz, zengin-fakir daima çatışma halindedir. Çok zengin biri bir anda fakir olabilmekte, çok fakir olan, sultanlar kadar zengin olabilmektedir. Böylelikle bünyesinde pek çok farklılığ barındıran masallar, okuruna daima ümitli olmayı aşılar. Çünkü masallar daima mutlu sonla biter.

7. Hayal Dünyasını Geliştirici Olarak Masallar: Yukarıdaki özelliklerin izahı yapılırken de değinildiği gibi; hayal dünyasını geliştirme özelliği masalların, en belirgin özelliklerinden biridir. Çocuğun hayal dünyası ne kadar gelişirse; düşünme kabiliyeti, orijinal işler yapması, o ölçüde de yaratıcılığının artması beklenir. Masallar, çocuğun gerçek dünyada bulamayacağı çok fazla malzemeyi bünyesinde barındırır. Bu malzemelerin her biri, çocuğun zihninde işleyerek ve birbirine ekleyerek genişleteceği bir halkanın zinciri mahiyetindedir.

8. Model İşlevi ile Masallar: Masallarda yer alan masal kahramanları; yaptıkları, başardıkları, doğruları ve yanlışları ile okuru için bir model işlevi görmektedir. Çocuk kendini kahramanın yerine koyabilmekte, olaylardan çıkarımlar yaparak gerçek hayatla özdeşleştirebilmektedir. Bu özelliğiyle masalların model işlevinin olduğu da görülmektedir. Model alma eğiliminde olan çocuk, okudukları ile kendisi arasında bir özdeşlik kurabilir. Bazılarının duygu, düşünce ve olaylar karşısındaki tutumlarını kendine mâl ederek hepsinden ortak bir çıkarıma varabilir. Böylelikle gözlemlediği modellerin hepsinin farklı bir yanını benimsediğinde, ortaya aykırılıkları da bünyesinde barındıran, kendini tanımaya ve kendi olmaya çalışan, kişiliği gelişme aşamasında bir fert çıkar. Zaman içerisinde bütün bu farklılıkları hazmettiğinde ve gereken olgunluğa eriştiğinde ise kişiliğini oturtmuş olur.

9. Aracı İşlevi ile Masallar: Öğrencinin dışa açılmadığı durumlarda içeriğiyle masallar; gördüğü model işlevi ile birlikte aracı konumuna da gelir ve öğrenci, masalda geçen olayla 
kendi yaşadıkları arasında özdeşlik kurarak, masallar vasıtası ile kendini ifade etmeye çalışabilir.

10. Depolayıcı İşlevi ile Masallar: Öğrenci, okuduğu masallarla pek çok hayat tecrübesi edinir. Bu tecrübeler, ilk bakışta anlaşılamayacak kadar çok ve karışık olabilir; fakat zaman içerisinde karşılaştığı olaylar doğrultusunda zihninde yer eden masallar o farkında olmadan gün yüzüne çıkıp ona yol gösterebilir. Bu açıdan bakıldığında masallar, depo gibidir; kişiyi uzun süre etkiler.

\section{Araştırmanın Amacı}

Çalışmanın amacı, sözlü kültür geleneğinin aktarıcısı olan masalların, Türkçe öğretiminde kaynak metin olarak kullanılabilirliğini tespit etmektir. Bu bağlamda, "Masallar, Türkçe ögretiminde kaynak metin olarak kullanılabilir mi?” sorusuna cevap aranmaktadır.

\section{Yöntem}

$\mathrm{Bu}$ bölümde araştırmanın modeli, evreni, örneklemi, sınırlılıkları ve verilerin toplanması ile analizi konularına yer verilmiştir.

\subsection{Araştırmanın Modeli}

Çalışmada, nitel araştırma yöntemlerinden “doküman incelemesi” yöntemi kullanılmıştır. Kuram oluşturma yaklaşımında görüşme, gözlem ve dokümanlar (yazılı ve görsel) en çok kullanılan veri toplama yöntemleridir. Doküman incelemesi, araştırılması hedeflenen olgu veya olgular hakkında bilgi içeren yazılı materyallerin analizini kapsar. Bu yaklaşım ile yapılan araştırmalarda doküman, gözlem ve görüşme verilerinden elde edilen kavramlar ve temalarla kuramın ilk işaretleri ortaya çıkar. Araştırma sürecinde ulaşılan kavram ve temalar anlamlı bir açıklama ortaya koyar. Bu açıklama veriler temelinde ortaya çıkan kuramdır (Y1ldırım ve Şimşek, 2013: 218).

\subsection{Evreni ve Örneklemi}

Araştırmanın evrenini ortaokul Türkçe ders kitapları oluşturmaktadır. Örneklemini ise 20112012 ve 2014-2015 eğitim öğretim yılında okutulan MEB yayınlarına ait Türkçe ders kitapları oluşturmaktadır.

\subsection{Sinırlılıklar}

Bu çalışma; 2011-2012 ile 2014-2015 eğitim öğretim yılında Millî Eğitim Bakanlığınca ders kitabı olarak okullarda okutulması uygun görülen Millî Eğitim Bakanlığı yayınlarına ait ortaokul 6., 7. ve 8. Sinıf Türkçe ders kitapları ile sınırlı tutulmuştur.

\subsection{Verilerin Toplanması ve Analizi}

Araştırmanın konusu bir metin türünün tespiti olduğu için en uygun veri toplama aracının doküman incelemesi olacağı düşünülmüştür. Araştırmada, var olan bir durumu ortaya koymak amaçlanmıştır. Bu amaca ulaşmak için öncelikle alan-yazın taraması yapılmış; bu alan-yazın taraması sonucunda ulaşılan sonuçlar doğrultusunda masal türünün Türk kültürü ve edebiyatındaki yeri göz önünde bulundurularak Türkçe eğitiminde kullanılması gerekliliği üzerinde durulmuştur. İkinci aşamada bu bilgiler ışığında Millî Eğitim Bakanlığı yayınlarına ait ortaokul Türkçe ders kitapları incelenmiştir. Veriler toplanırken araştırmada nitel veri kaynağı olarak ilgili literatür, yapılan benzer çalışmalar ve Millî Eğitim Bakanlığı yayınlarına ait ilköğretim ikinci kademe Türkçe ders kitapları kaynak alınmıştır. 


\section{Sonuç}

Millî Eğitim Bakanlığı İlköğretim Türkçe Dersi (6, 7, 8. sinıflar) Öğretim Programında; “6, 7, 8. Sinıflarda Yer Verilmesi Gereken Türler” başlığı altında masal türüne sadece 6. Sınıflar için yer verilmiştir (MEB, 2006: 57). Oysa "Bir Orman Masalı" isimli metin 7. sınıf kitabında yer almaktadır ve bu kadarı bile yeterli değildir. 2011-2.012 eğitim öğretim yılı için Millî Eğitim Bakanlığı'nın hazırlamış olduğu Türkçe ders kitapları incelendiğinde masal türüne ait iki metne rastlanmaktadır. Bu metinlerden biri 6. Sınıf Türkçe Ders Kitabında yer alan "Çocuk Kitaplığında Sabah Tartışması" isimli metindir. Diğeri ise kitabın geçen seneki baskılarında yer almayan, ilk baskısında 8. Sınıf kitabı içerisine yerleştirilen, daha sonraki dönemde kaldırılarak 2011 yılında kitabın 5. Baskısı yapılırken "Serbest Okuma Metni" başlı̆̆ı altında kitabın en son metni olan "Toplum Hayatı" teması içerisine tekrar eklenen "Bir Orman Masalı" isimli metindir. Bunun dışında 8. sınıf Türkçe ders kitaplarında bu türe hiçbir şekilde rastlanmamıştır. Ders kitaplarında en çok hikâye türüne ağırlık verildiği görülmektedir.

2014-2015 eğitim öğretim yılı için Millî Eğitim Bakanlığının hazırlamış olduğu Türkçe ders kitapları incelendiğinde masal türüne ait tek bir metin bulunmuştur. 6. Sınıf Türkçe ders kitabında yer alan Kuğular isimli bu metin Ziya Gökalp'e aittir. Masal türü sadece ilkokul çağındaki çocukların gelişimi için değil, ortaokul çağındaki çocukların gelişimi için de önemlidir. Masallar, her yaştan insan içindir ve insanda hayal etme yeteneği oldukça hep var olacaktır (Şirin, 2007: 33).

Gerek çocuklara, gerekse yetişkinlere hitap eden sözlü edebiyat geleneğimizin en önemli unsurlarından biri olan masalların (Şirin, 2007: 80; Boratav, 1973: 85; Güzel, 2012: 464; Karatay, 2007: 471; Y1lmaz, 2012: 301; Mert, 2012: 9; Tok, 2012: 52) eğitimdeki önemi üzerinde sıkça durulsa da, bu edebî türün ders kitaplarına aynı ölçüde yansımadığı görülmüştür. Yeni yönteme göre hazırlanan Türkçe ders kitapları daha başarılı bulunsa da başka açılardan eksiklikler göze çarpmaktadır. Bu eksikliklerin başında ise seçilen metinlerin dilbilgisi yönünden eksikliği yer almaktadır. Yapılan bir araştırmada; ilköğretim 7. sınıf Türkçe ders kitabındaki edebî metinler, temel evrensel değerler içermesi bakımından incelenmiştir. Çalışmada varılan sonuç; yüzlerce yıllık bir birikime sahip olan Türk edebiyatı ve bunun yanı sıra dünya edebiyatlarından hemen her konuda çok kaliteli metin örnekleri seçmek yerine kitabı hazırlama aşamasında kolaya kaçıldığı, iyi bir tarama yapılmadığı olmuştur (Somuncu, 2008: 113). Dil bilgisi yönünden incelendiğinde de benzer sonuçlar elde edilmiştir (Karakuş, 2014: 588; İşeri, 2006: 71).

İşcan vd. (2007: 14)'nin ders kitaplarında yer alan edebî metinlerin estetik zevk kazandırmadaki rolünü inceledikleri çalışmalarında masalların öğrencilerin Türkçe öğretimindeki dört temel dil becerisinden ikisi olan okuma ve dinlemeye yönelik istek ve alışkanlıklarını arttırıcı olduğuna dair görüşleri yer almaktadır. Bunun içinı de seçilecek masal örneklerinin ilgi çekici ve sürükleyici olmasına özen gösterilmelidir.

Türkçe ders kitaplarında yer alan metinleri tür ve tema yönünden inceleyen Özbay ve Çeçen (2012: 73), Milli Eğitim Bakanlığı Talim ve Terbiye Kurulunun 2006-2007 yılından başlayarak ilköğretim okullarının 6,7 ve 8 . sınıfları için 5 yıl süreyle ders kitabı olarak kabul ettiği MEB ve Pasifik yayınevlerince hazırlanan Türkçe ders kitaplarındaki türleri tespit etmişlerdir. Onların tespiti de bu çalışmayı destekler niteliktedir. Milli Eğitim Bakanlığı 
yayını olan Türkçe ders kitabında 6. ve 7. sınıflarda masal türünden birer örneğe yer verilirken, Pasifik yayınlarının kitabında 6 . sınıflarda sadece bir örneğe yer verilmiştir. Her iki kitapta da 8. Sinıflarda masal türüne ait bir örnek mevcut değildir.

Altıncı sınıf Türkçe ders kitaplarındaki metin türleri üzerine bir inceleme yapan Baş (2003: 259), incelediği MEB yayınevine ait 6 . Sınıf Türkçe ders kitabında masal türüne ait sadece bir örnek tespit etmiştir. İlköğretim Türkçe ders kitaplarını türler açısından inceleyen bir başka çalışma da Solak ve Yaylı'nın (2009: 451) çalışmalarıdır. Meb, Koza, Pasifik ve Batu yayınevlerinin Türkçe ders kitaplarının incelendiği çalışmada masal türüne ait toplamda 6 . sinıfta 3, 7. sınıfta 0, 8. sınıfta 2 metin örneği tespit edilmiştir.

Yukarıdaki benzer çalışmalar ve yapılan bu çalışma da göstermektedir ki ortaokul öğrencileri için önemli bir tür olan masal türüne, Millî Eğitim Bakanlığı onaylı ilköğretim 6., 7. ve 8 . sınıf Türkçe ders kitaplarında yeterince yer verilmemektedir. Bir diğer husus da Türkçe ders kitapları hazırlanırken yüzlerce yıllık bir masal birikimine sahip olan Türk Edebiyatının seçkin masal örneklerinden yararlanılmamış olunduğudur.

\section{5. Öneriler}

İlkokul Türkçe ders kitaplarında olaya dayalı veya öyküleyici metin türlerinin bilgilendirici metin türlerinden fazla kullanılması daha uygundur. Öyküleyici metin türlerinden -masal, fabl, hikâye, efsane, destan, roman, tiyatro, anı ve gezi yazısından- masal, fabl, hikâye, anı ve gezi yazısı metin türlerini kullanmak çocukların için daha etkili, zevkli ve heyecanlıdır. Çocuklara okuma alışkanlığı kazandırmak için masal, fabl, hikâye metin türünün daha çok üzerinde durulması gerekir. Özellikle masalın çocuklarda hayal ve duygu gücünü arttırdığ1 ve zenginleştirdiği, anadilin kavranması ve geliştirilmesinde büyük payı olduğu görüşünde uzmanlar birleşmektedir. Ayrıca Millî Eğitim Bakanlığı İlköğretim Türkçe Dersi (6, 7, 8. sınıflar) Öğretim Programında, "Okuma Metinlerinde Bulunması Gereken Özellikler" başlığı altında yer alan maddelerden 10. maddede: "Metinler, Türkçenin anlatım zenginliklerini ve güzelliklerini yansıtan eserlerden seçilmelidir." cümlesi yer almaktadır. Türkçe ders kitaplarında Türk edebiyatının seçkin örneklerine daha çok yer verilmesi önerilmektedir. 


\section{REFERENCES}

- Alptekin, A. B. (2002). Taşeli Masalları, Ankara: Akçağ Yay.

- Arıcı, A. F. (2012). Masalın Sesi, Ankara: Pegem A Yayıncılık.

- Baş, B. (2003). Altıncı Sınıf Türkçe Ders Kitaplarındaki Metin Türleri Üzerine Bir İnceleme, Türklük Bilimi Araştırmaları Dergisi, 13, 257-265.

- Boratav, P. N. (1973). 100 Soruda Türk Halk Edebiyatı. İstanbul: Gerçek Yayınevi.

- Büyük Laouresse. (1992). İstanbul: Gelişim Yayınları.

- Cemiloğlu, M. (2004). Türkçe Öğretimi. İstanbul: Aktüel Yayınevi.

- Çeşitli, İ. (2006). Edebiyat Eğitimi'nde Edebî Metnin Yeri ve Anlamı, Millî Eğitim Dergisi, 169, 75-84.

- Durmuşoğlu, G. (1987). Metin dilbilim, Çeviri süreci ve çeviri değerlendirilmesi 23.02.2015 tarihinde http://www.ceviribilim.hacettepe.edu.tr/art/i01-09.pdf web sitesinden alınmıştır.

- Günay, U. (1975), Elazığ Masalları, Erzurum: Atatürk Üniversitesi Basımevi.

- Güzel, A.; Torun, A. (2012). Türk Halk Edebiyatı El Kitabı. Ankara: Akçağ Yayınları.

- Işık, N. (2009), Türk Masallarının Sembolik Açıdan Çözümlenmesi / A Symbolıc Analysis of Turkish Tales (Frrat Üniversitesi Sosyal Bilimler Enstitüsü Yayımlanmamış Doktora Tezi).

- İşcan, A.; Efendioğlu, S.; Ada, Ş. (2007). Türkçe Ders Kitaplarında Yer Alan Edebî Metinlerin Öğrencilere Estetik Zevk Kazandırmadaki Rolü, Gaziosmanpaşa Üniversitesi Sosyal Bilimler Enstitüsü Sosyal Bilimler Araştırmaları Dergisi, 2, 59-76.

- İşeri, K. (2006). Altıncı Sınıf Türkçe Ders Kitabının İlköğretim Türkçe Programının Amaçlarının Uygunluğunun Değerlendirilmesi, Dil Dergisi, Sayı 136, S.58-74

- Karakuş, N. (2014). Türkçe Ders Kitaplarındaki Metinlerin Dil ve Anlatım Yönünden Değerlendirilmesi. Journal of History School. 7 (18), 567-593.

- Karakuş, N. (2012). Türkçe Öğretiminde Kaynak Metin Kullanımı (1. Baskı). Ankara: Pegem A Yayıncilık.

- Karatay, H. (2007). Dil Edinimi ve Değer Öğretimi Sürecinde Masalın Önemi ve İşlevi, Türk Eğitim Bilimleri Dergisi, 5 (3), 463-475.

- Kavcar, C.; Oğuzkan, F.; Sever, S. (2004). Türkçe Öğretimi (7. Baskı). Ankara: Engin Yayınevi.

- Keklik, S. (2009). On bir Yaşına Kadar Çocukta Dil Edinimi. Yayınlanmamış Doktora Tezi, Marmara Üniversitesi Eğitim Bilimler Enstitüsü.

- Komisyon (2011). İlköğretim Türkçe 6. Sınıf Ders Kitabı. Ankara: Millî Eğitim Bakanlığı Yayınları.

- Komisyon (2011). İlköğretim Türkçe 7. Sınıf Ders Kitabı. Ankara: Millî Eğitim Bakanlığı Yayınları.

- Komisyon (2011). İlköğretim Türkçe 8. Sınıf Ders Kitabı. Ankara: Millî Eğitim Bakanlığg Yayınları.

- Komisyon (2014). İlköğretim Türkçe 6. Sınıf Ders Kitabı. Ankara: Millî Eğitim Bakanlığı Yayınları.

- Komisyon (2014). İlköğretim Türkçe 7. Sınıf Ders Kitabı. Ankara: Millî Eğitim Bakanlığı Yayınları.

- Komisyon (2014). İlköğretim Türkçe 8. Sınıf Ders Kitabı. Ankara: Millî Eğitim Bakanlığı Yayınları. 
- Mert, E. L. (2012). Anadili Eğitimi Öğretimi Sürecinde Çocuk Y'azını Ürünlerinden Yararlanma ve Masal Türüne Yönelik Bazı Belirlemeler, Pamukkale Üniversitesi Eğitim Fakültesi Dergisi, 31 (1), 1-12.

- Milli Eğitim Bakanlığı Talim ve Terbiye Kurulu Başkanlığı (2006). İlköğretim Türkçe Dersi 6, 7, 8. Sınıflar Öğretim Programı, Ankara: Milli Eğitim Yayınevi.

- Öcal, A. (2002). "Bulgaristan Türk Masalları ile Yozgat (Karakuyu) Masallarının" Karşılaştırılması, Sosyal Bilimler Enstitüsü Dergisi, Sayı: 13, s. 113-123.

- Özbay, M.; Çeçen, M. A. (2012). Türkçe Ders Kitaplarında Yer Alan Metinlerin Tür ve Tema Açısından İncelenmesi, Dil ve Edebiyat Eğitimi Dergisi, 1 (1), 67-76.

- Özden, M. (2009). Kaynak Türkçe Metinler (1. Bask1). İstanbul: Ürün Yayınları.

- Sakaoğlu, S. (2002). Gümüşhane ve Bayburt Masalları, Ankara: Akçağ Yay., (Birinci bask1: 1973).

- Sever, S. (2004). Türkçe Öğretimi ve Tam Öğrenme, Ankara: Anı Yayıncılık.

- Seyidoğlu, B. (1975). Erzurum Halk Masalları Üzerinde Araştırmalar, Ankara: Atatürk Üniversitesi Yayınları.

- Solak, M.; Yaylı, D. (2009). İlköğretim İkinci Kademe Türkçe Ders Kitaplarının Türler Açısından İncelenmesi, Uluslararası Sosyal Araştırmalar Dergisi, 2 (9), 444453.

- Somuncu, S. (2008). İlköğretim 7. Sınıf Türkçe Ders Kitabındaki Edebî Metinlerin Temel Evrensel Değerleri İçermesi Bakımından İncelenmesi. Yayınlanmamış Yüksek Lisans Tezi, Afyonkarahisar Kocatepe Üniversitesi Sosyal Bilimler Enstitüsü.

- Şimşek, E. (2001). Yukarıçukurova Masallarında Motif ve Tip Araştırması I-II, Ankara: T.C. Kültür Bakanlığı Yay.

- Şirin, M. R. (2007). Masal Atlası. İstanbul: Kök Yay.

- Tok, M. (2012). Mesnevi'deki Masalların Farklılığı ve Eğitimsel İşlevleri. Dil ve Edebiyat Eğitimi Dergisi, 4, 42-57.

- Türk Ansiklopedisi(1973). Ankara: MEB Yay.

- TDK Büyük Türkçe Sözlük(2010). Ankara: Türk Dil Kurumu Yayınları.

- Türk Lehçeleri Sözlüğü(1991). Ankara: TDK Yayınları.

- Yıldırım, A; Şimşek, H. (2013). Sosyal Bilimlerde Nitel Araştırma Yöntemleri. Ankara: Seçkin Yayınevi.

- Yılmaz, A. (2012). Çocuk Eğitiminde Masalın Yeri, Süleyman Demirel Üniversitesi Fen Edebiyat Fakültesi Sosyal Bilimler Dergisi, 25, 299- 305. 